\title{
Political and legal thought
}

SOPHIE E. B. NICHOLLS

In Machiavelli's The Prince, the author commented that the French did not understand statecraft because they allotted too much power to the church. Machiavelli's distinctive view of 'statecraft' sought to replace medieval ideas of ars regiminis ('the art of governing') underpinned by the principles of natural and divine law which are noticeably absent from his political analysis. His scathing views of French politics were prompted by his observations of what he considered to be the failings of Louis XII's policies, but they hold a deeper interest when it comes to characterising French political thought in the later sixteenth century. The combination of the impact of the Reformation in France with a monarchy weakened by successive minority rule produced a combustible situation in which rulers and subjects fought over the role of religion in their polity. Reflections on the art of governing were entangled in questions of the origins and location of sovereign power in France, and the relationship of that power to both the Gallican and universal church. The responses of French theorists to Machiavelli in this period reveals the centrality of the relationship between politics and religion in their political thought.

Machiavelli's attempt to strip away the trappings of medieval theology, particularly Thomist-Aristotelianism, from politics was met with a divided response in France. On the one hand, he provided scholars with a fresh intellectual approach. In his translation of The Prince into French in 1553 Guillaume Cappel commented on the wisdom of providing such 'strong medicine' for the ailments of the body politic. Charles Dumoulin, the influential jurist who had prominently rejected the authority of the Council of Trent in 1564 , revelled in the intellectual resources of one who had so plainly revealed the ruses of the popes in their bid to extend their temporal dominion. But on the other hand, Machiavelli's subversion of classical 
conceptions of virtue and rejection of theological explanations for the purpose of political life prompted aggressive condemnation of his perceived atheism and lack of morality. This attitude to Machiavelli was intensified as the Wars of Religion progressed along their bloody path and became particularly evident in the wake of the St Bartholomew's Day Massacre of 1572.

French Huguenots responding to the problems of tyrannical rule blamed Machiavelli for influencing Catherine de Medici in her role in the assassination of the Huguenot leader, Gaspard de Coligny, that precipitated a mass slaughter of French Protestants in Paris and the provinces. Huguenots charged Medici with treating The Prince like her bible, and using it to instruct her children. Innocent Gentillet wrote an authoritative rejection of Machiavellian principles in his Anti-Machiavel (1576) and François de la Noue argued in 1587 that Machiavelli was responsible for the mass conversion of Europeans to atheism. But what is striking about these Protestant rejections of Machiavelli is that they used him as a tool to appeal to both Catholic and Protestant readers and so to gloss over the effect of confessional division on French political life. This was a tactic notably employed in the Vindiciae, contra Tyrannos (1579). Like other resistance theories, including Théodore de Bèze's De Jure Magistratuum (1574), the intended effect was to focus attention on the problem of tyranny instead of the presence of the reformed religion and to construct an argument for popular sovereignty centred on the role of the Estates General. However, the urgency of antiMachiavellian wake-up calls like Le Reveille-Matin des François (1574) did not manage to persuade Catholic readers sceptical of toleration.

In Catholic works anti-Machiavellianism was used to express anger at what was perceived as the absence of the 'true' religion in politics, especially in writings produced by members of the Catholic League who emphasised the political role of the French clergy in response to Huguenot attempts to remove them from the political process. The League 
originated in 1576 in reaction against Henri III's attempts at religious toleration, and reformed in 1584-5 in response to the succession crisis which placed the Protestant prince Henri de Navarre in line to the throne. One of its leading theologians, Jean Boucher, claimed that Henri III carried around a copy of The Prince with him, consulting it whenever he needed to be his most evil. Boucher's De Justa Abdicatione Henrici Tertii (1589) was written to justify the deposition and subsequent assassination of Henri III, on the basis that Henri had acted tyrannically in his assassination of the two Guise brothers who had played a leading role in the League. It was a work underpinned by the principle that the contractual allegiance between ruler and ruled, the provisions of which were founded on the oath taken by the monarch at the coronation ceremony, could be broken. Yet as the Scottish jurist William Barclay correctly observed in his De Regno et Regali Potestate (1600), in constructing a series of contractual obligations between monarch and people to explain the legitimacy of political resistance Boucher had ruthlessly plundered the Vindiciae. It is ironic that Boucher's text demonstrates the effectiveness of attempts by Huguenot writers to use antiMachiavellianism as a way of appealing to Catholic readers.

At the heart of French responses to Machiavelli in the second half of the sixteenth century lies the question of how the two 'ends' for human life related: the good, and the Christian good. The fundamental Aristotelian question of how the ethical life related to the political life, or the good man to the good citizen, continued to be played out in this Thomist intellectual arena wherein knowledge of God was the primary qualification for an understanding of the common good. It is no surprise therefore, that notwithstanding prevailing Humanist claims to have rejected the Aristotelian corpus, French political thought continued to depend heavily on that body of material (and to Scholasticism more broadly conceived). This dependence is aptly demonstrated by Louis Le Roy's influential translation of and commentary on Les Politiques d'Aristote (1568). There was also a connection between 
the Aristotelian language of politics and responses to Machiavellian statecraft. Machiavelli and his followers were often tarred with the label 'Politique' in this period, used to denote those who separated Christian morality from political life. But this terminology could also retain its Aristotelian inflection, referring to the role of the good statesman or lawgiver. In a third permutation, it was adopted by the lawyers to denote their own intellectual trade as the definition of political science, as in François Baudoin's Commentarius de jurisprudentia muciana (1559) and Louis Le Caron's Pandectes (1587). Finally, an underlying Augustinian anxiety underpins debates between Huguenots and Catholics wrestling with the terminology of the political expert which signifies an understanding that justice could not be meted out without the guiding hand of the church. This is demonstrated usefully in the Huguenot dialogue Le Politique (1574), an anonymous League pamphlet entitled Descripton (sic) $d u$ Politicque de nostre temps (1588) and Louis Dorléans' Le banquet et aprèsdisnée (sic) du conte d'Arete (1594). The terminology of politics and the political man played a central role in French attempts to bring clarity to the 'correct' relationship between statecraft, jurisprudence and religion in which politics was conceived as an activity promoting the common good conceived in Christian terms.

The definition of Politique was dependent on the concept of the politeia, translated as la police in the vernacular, and both terms were deemed to require clarification in this period. Like its original la police was a polysemic term that thinkers used to focus on three areas: the relationship of the sovereign to the politeia or respublica; the identity of the citizen body as a reflection of the constitution; and the concept of the 'ancient' constitution. Knowledge of $l a$ police understood broadly as political organisation was as a result an essential component of knowledge of 'statecraft', civil science, or the art of governing - all variants of the same political discussion that continued to be integrated into ecclesiology. Lawyers in the period, notably Charles de Grassaile, were particularly focussed on the definition of the regalian 
rights, which included rights over the church. In his De Domanio Franciae (1574) and De Sacra Politia (1577) René Choppin argued that the king's responsibilities to protect and preserve the public domain without alienating it extended to the church. Choppin wrote that ecclesiastical-royal relations did not belong to two separately defined sciences, but to one and the same body of knowledge; in Choppin's understanding the police of the church formed the rational soul of the Christian commonwealth, an idea that would later be built upon influentially by Pierre Grégoire in his De Republica (1596). Choppin's commitment to this integration of civil and religious science led to his involvement in the League in the late 1580s. His work was ridiculed by Jean Hotman in the Anti-Choppinus of 1592 for its defence of papal power, but nevertheless Choppin's formulation of the science of police indicates how intimately connected this could be to the science of jurisprudence.

The concept of la police could also be used to explain the idea of the ancient (and often mixed) constitution, an idea that embodied two conflicting intellectual impulses: one to preserve, and the other to restore. The former was underpinned by concepts of 'fundamental law', and the latter disguised innovation as restoration in the name of French political liberty. The idea that the French had always been 'franc et libre' ('Frank and free') was influentially revived in this period. In Etienne Pasquier's Récherches de la France produced from the 1560 he demonstrated the ways in which the ancient Gauls had laid foundations for la police in such a way as to ensure political liberty, as opposed to tyranny, a foundation complemented on the arrival of the Franks. When Pasquier described the French as 'Frank and free' he was referring to this primitive Teutonic virtue. These claims received their most polemical formulation in François Hotman's Francogallia (1573) which offered a legalhistorical basis for an argument for royal election grounded in antiquity. Hotman argued that as French kings had always been elected they could also be deposed if they failed to live up to the conditions of their election. Hotman's great contribution to political thought in the 
period was his ability to exploit the legal tradition of the mos gallicus, the study of native rather than Roman law, to a polemical advantage. In this emphasis on customary law as a source of Gallican liberty he was influenced by Charles Dumoulin and his arch-enemy René Choppin.

Ancient constitutionalism could also prompt deep reflection on ways to respond to confessional division in France. In his essay 'De la liberté de conscience' (II.19), for example, Michel de Montaigne suggested that those who upheld the ancient religion and police took the soundest position in the Wars of Religion, as long as their passions weren't swayed to violent extremes (he was alluding to the League). Earlier in the century Claude de Seyssel had suggested one influential approach to the relationship between religion and police. In La Grande Monarchie (1519) he described them as two of three brakes on royal power, the third of which was justice. But in 1571 Gerard du Haillan commented that those institutions may once have been as magnificent as Seyssel had suggested, yet in present times they had become fractured and the monarchy corrupted; France only retained the shadow of la religion, la police and la justice. In response to the dilemma presented by confessional division Catholics opted either to separate religion and police, or to bind them more closely together. Pierre de Belloy argued in his Apologia Catholica (1584), written in favour of Henri de Navarre's claim to the throne, that ecclesiastical jurisdiction and temporal government needed to be clearly separated. In response to Belloy, Louis Dorléans argued that he was the worst kind of heretic, and that religion was not a Scylla or Charybdis to be avoided in political life, but to be embraced as its destination. In the view of Dorléans Belloy and his 'Politique' friends usurped the name of Catholic, and therefore had nothing about them reminiscent of the customs and virtue of the ancient French people. 
Although often associated with arguments for restraining royal authority on a constitutional basis, the concept of la police could also be used to underpin theories of absolute royal power. This was achieved through exploiting the ambiguities of Aristotle's concept of politeia. In his translation of Politics 3.6 Louis Le Roy perpetuated a traditional royalist interpretation of Aristotle in keeping with his views on French politics when he defined la police to mean either the town or city; or to refer to seigneurie ('lordship') and public government over a community of men governed by the same laws and magistrates. Le Roy was careful to identify la police with a method of government distinct from the citizen body, not synonymous with it. Belloy capitalised on this line of approach in his Apologia Catholica and De l'autorité du Roy (1587). In doing so he resourcefully (and ironically) built on René Choppin's arguments. Belloy explicitly targeted les papicoles (literally ‘those belonging to the pope') and he included the church in the king's domain, using the concept of la police to argue for full sovereignty over both the church and the civil community in France. He interpreted the French king's role as being the mouth and organ of la police which, he argued, remained silent unless the king spoke. Belloy's analysis of royal and papal power was sufficiently provocative that it drew fire from the great Catholic polemicist of the sixteenth century, Cardinal Bellarmine, who wrote an attack on the Apologia Catholica published in Latin and French in 1588.

Belloy's work is often compared to that of Jean Bodin, an interpretation which can be misleading. However what the two have in common in their attempts to reformulate civil science in opposition to resistance theorists is the idea that obedience to the sovereign and laws was inbuilt in the political system. Bodin's concept of civil science was constructed in explicit opposition to Machiavelli in arguing that a true understanding of political life was impossible without comprehensive knowledge of the laws. Bodin defined sovereignty as the 'absolute and perpetual power of the commonwealth' in which sovereign power (like the 
kingdom itself) was inalienable. His sovereign was legibus solutus, freed from the laws, an idea framed by imperial, Roman law arguments for the fullness of power. Yet the ruler remained bound to the dictates of divine, natural and fundamental law. Strikingly, Bodin articulated a distinction between l'état ('the state') and la police in his République. His conception of police is connected to his analysis of French customary law in which he was also influenced by Choppin, whom he counted as a close friend. There were two types of political wisdom in operation in the Six Livres, architectonic (of the sovereign) and political (of the magistrates) and by striking an important balance between these Bodin allowed for the legal complexities of the localities in the mosaic kingdom that was France, and simultaneously created a thesis of a unified, sovereign whole in which the sovereign could not destroy his own power, an argument that would prove deeply influential for seventeenth century theories of sovereignty.

Even though he sought to replace Machiavelli's interpretation of political science in his République with his own juridical conception, Jean Bodin was probably the most likely of all the thinkers mentioned in this chapter to meet Machiavelli's requirements for statecraft. But in his attitude to natural and divine law Bodin remained within a system of French political and legal theory that continued to debate and reflect upon the medieval synthesis of kingdom and priesthood, a fact which goes some way towards explaining his complex relationship with the Catholic League. In this period, even as theorists made important innovations in their attitude to statecraft and jurisprudence they remained loyal to the traditional structures of French thought, the parameters of which were established by theories of Gallican liberty. As much as contemporaries from Michel de L'Hopitâl, Étienne Pasquier and Michel de Montaigne to Philippe Duplessis Mornay might have considered and argued the case for religious toleration in France, it fell on stony ground in a country where unity of the kingdom had been predicated on unity of the church for centuries. Furthermore, these 
discussions continued to influence theological-political debate in the context of the Oath of Allegiance controversy (1606-c.1613), the assassination of Henri IV (1610), and - within a century - the revocation of the Edict of Nantes (1685). 
Further reading:

Franklin, J.H. Jean Bodin and the Sixteenth Century Revolution in the Methodology of Law and History, New York, Columbia University Press, 1963.

Garnett, G. 'Scholastic thought in humanist guise: François Hotman’s ancient constitution', The Medieval World, 2nd edn., ed. P. Linehan and M. Costambeys, London, Taylor and Francis ltd., 2017.

Giesey, R.E. Rulership in France, 15th-17th Centuries, Aldershot, Ashgate 2004

Kelley, D.R, Foundations of Modern Historical Scholarship, Columbia, Mo. 1970;

'Murd'rous Machiavel in France: a post-mortem', Political Science Quarterly, vol. 85, no.4 (1970): 545-559.

Keohane, N.O, Philosophy and the State in France, Princeton, Princeton University Press, 1980.

Lemaire, A. Les lois fondamentales de la monarchie française d'après les théoriciens de l'ancien régime, Paris, A. Fontemoing, 1907

Nicholls, S.E.B. 'Gallican liberties and the Catholic League.' History of European Ideas Vol. 40 (2014), 940-964; 'De Justa Reipublicae Christianae in Reges Impios et Haereticos Authoritate (1590): questions of authority and heretic kings in the political thought of the 
Catholic League.' Bibliothèque d'Humanisme et Renaissance Vol. 77 (2015): 81-101.

Salmon, J.H.M. Renaissance and Revolt. Essays in the intellectual and social history of Early Modern France, Cambridge, Cambridge University Press, 1987.

Senellart, M. Les arts de gouverner. Du regimen médiéval au concept du gouvernement, Paris, Editions du Seuil, 1995.

Skinner, Q. Foundations of Modern Political Thought, 2 vols., Cambridge, Cambridge University Press, 1978.

Vindiciae, contra Tryannos: or, concerning the legitimate power of a prince over the people, and of the people over a prince, ed. and trans. G. Garnett, Cambridge, Cambridge University Press, 1994. 